\title{
Serum insulin-like growth factor-1 and its binding protein 3 as prognostic factors for the incidence, progression, and outcome of hepatocellular carcinoma: a systematic review and meta- analysis
}

\author{
Jing Wang ${ }^{1, *}$, Yu-Chuan Li ${ }^{2, *}$, Min Deng ${ }^{2}$, Hai-Yin Jiang ${ }^{2}$, Li-Hua Guo' ${ }^{2}$, Wen-Juan \\ Zhou ${ }^{3}$ and Bing Ruan ${ }^{2}$ \\ ${ }^{1}$ Department of Cardiology, The First Affiliated Hospital, School of Medicine, Zhejiang University, Hangzhou, Zhejiang, China \\ ${ }^{2}$ State Key Laboratory for Diagnosis and Treatment of Infectious Diseases, Collaborative Innovation Center for Diagnosis and \\ Treatment of Infectious Diseases, The First Affiliated Hospital, School of Medicine, Zhejiang University, Hangzhou, Zhejiang, China \\ ${ }^{3}$ Department of Health Management Center, Wuxi Third People's Hospital, Wuxi, Jiangsu, China \\ *These authors contributed equally to this work
}

Correspondence to: Bing Ruan, email: hzruanbing@gmail.com

Keywords: insulin-like growth factor-1, IGF-binding protein-3, hepatocellular carcinomas, overall survival, time-to-progression Received: December 06, 2016

Accepted: June 20, 2017

Published: July 12, 2017

Copyright: Wang et al. This is an open-access article distributed under the terms of the Creative Commons Attribution License 3.0 (CC BY 3.0), which permits unrestricted use, distribution, and reproduction in any medium, provided the original author and source are credited.

\section{ABSTRACT}

Purpose: Previous studies have supported an association between serum insulin-like growth factor-1 (IGF1) and IGF-binding protein 3 (IGFBP3) levels and hepatocellular carcinoma (HCC), but the results were inaccurate. It has recently been proposed that IGF1 and IGFBP3 play roles in the time-to-progression (TTP) and overall survival (OS) of HCC patients. Our results revealed that serum IGF1 level is predictive of the progression and survival of HCC patients.

Results: HCC was associated with a significant reduction in serum IGF-1 and IGFBP-3 levels compared to cirrhosis $(p=0.037)$. Low serum IGF1 levels were predictive of a shorter TTP (OR, 2.74; 95\% confidence interval $[\mathrm{CI}], 1.92-3.90)$ and poorer OS (odds ratio [OR], 2.20; 95\% CI, 1.81-2.68) in HCC patients. The IGF1/ IGFBP3 molar ratio was not significantly associated with the risk of HCC (OR, 1.311; 95\% CI, 0.761-2.260).

Materials and Methods: We conducted a comprehensive literature search in PubMed, EMBASE, and the Cochrane Library. Twenty studies met the inclusion criteria and were subjected to statistical analysis. The geometric mean and standard deviation (SD) of serum IGF1 and IGFBP3 levels in the healthy, cirrhosis, and HCC groups were calculated. Pooled odds ratios (ORs) were calculated using a fixed-effects model to analyse the association of serum IGF1 level with the progression and survival of HCC patients.

Conclusions: Serum IGF1 and IGFBP3 levels were positively associated with the incidence of HCC. Serum IGF1 level is an independent prognostic factor for the progression and survival of HCC patients.

\section{INTRODUCTION}

Hepatocellular carcinoma (HCC) is the third leading cause of cancer-related deaths worldwide. In the past two decades, the role of the IGF axis in the pathogenesis of various neoplasms, including HCC, has been a focus of research [1]. Some case-control studies have supported a positive association between the insulin-like growth factor- 1 (IGFI) level and the risk of liver cancer [2-4]. Indeed, in clinical practice, IGFI is used to assess HCC reserve capacity $[5,6]$ and as a prognostic marker for HCC progression and survival [3]. However, further research is needed. 
Insulin-like growth factor-1 (IGF1), which is synthesised by the liver, is an important regulator of cellular proliferation, differentiation and apoptosis [7-9]. These effects can be inhibited by IGFBP3, which binds to and prevents IGFI from binding to type 1 insulinlike growth factor receptor (IGFI-R) [10]. About 99\% of circulating IGF1 is bound to IGF-binding proteins, with most bound to IGF-binding protein 3 (IGFBP3). Less than $1 \%$ of circulating IGF1 is in an unbound form [11]. The IGF system is involved in the pathogenesis of several malignancies, including breast, prostate, colorectal, and gastric cancer [7, 9]. The development of HCC is reportedly correlated significantly with low IGFI and IGFBP3 levels and a high IGFI/IGFBP3 molar ratio [12-14]. Additionally, low baseline serum IGF1 levels are reportedly associated with shorter time-to-progression (TTP) and poorer overall survival (OS) in patients with $\mathrm{HCC}$, irrespective of the grade of hepatic dysfunction $[15,16]$. However, these studies were hampered by their low quality and small sample sizes. We performed a systematic review and meta-analysis of 20 studies to investigate the associations of IGF 1 components with HCC and to examine their ability to predict the survival and prognosis of HCC patients.

\section{RESULTS}

\section{Literature search and selection}

Initially, 1172 records were retrieved by searching the Cochrane Library, PubMed, and EMBASE databases. After removal of duplicates, 834 articles were screened. Of these articles, 732 were excluded by reading the titles and abstracts, and the remaining 102 articles underwent detailed evaluation of the full text. A further 82 studies were excluded as they did not meet the inclusion criteria. Finally, 20 studies were included in our systematic review and meta-analysis: 3 case-control and 17 cohort studies (Figure 1). Eleven studies investigated the roles of IGF-1, IGFBP3, and the IGF-I/IGFBP3 molar ratio in the development of HCC (Table 1A), and nine studies assessed the ability of serum IGF1 level to predict the TTP and OS of HCC patients (Table 1B).

\section{Characteristics of participants}

The characteristics of the participants are presented in Table 1A and 1B. The study involved 1,798 HCC patients, 324 cirrhosis patients, and 1,502 healthy controls. The studies were published from 2000 to 2016. Seventeen were hospital-based studies, and three were populationbased studies. Six studies were performed in Europe, four in the United States, four in Africa, and six in Asia. Of the 20 studies, 3 were case-control studies, and 17 were cohort studies; all involved only adults. Serum IGF1 and IGFBP3 levels were tested by enzyme-linked immunosorbent assay
(ELISA) in all of the studies. The diagnosis of HCC was established based on biopsy, elevated alpha-fetoprotein level (AFP), and imaging techniques — such as ultrasound (US), three-phase dynamic computed tomography (CT), and magnetic resonance imaging (MRI) — according to the guidelines of the American Association for the Study of Liver Diseases [17].

\section{Serum IGF1 and IGFBP-3 levels in the healthy, cirrhosis, and $\mathrm{HCC}$ groups}

The geometric mean serum levels of IGF1 and IGFBP3 differed significantly among the healthy, cirrhosis, and HCC groups independently of the degree of impairment of liver function (Table 2). The serum IGF-I and IGFBP3 levels of the healthy group were significantly higher than those of the cirrhosis group $(p<0.01)$. HCC was associated with lower serum IGF1 and IGFBP3 levels compared to liver cirrhosis $(p=0.037)$. The effects of different detection methods (ELISA and radioimmunoassay), research designs (case-control, cohort, and cross-sectional study), settings (hospital- and population-based), and locations (Asia, North America, and Europe) on serum IGF1 levels were assessed. In HCC patients, there was no difference between cohort and cross-sectional studies $(p=0.056)$ or between data collected in hospital- and population-based settings $(p=0.367)$ (Table 3$)$. Additionally, we assessed the association between the IGFI/ IGFBP3 molar ratio and the risk of $\mathrm{HCC}$, odds ratio (OR, $1.311 ; 95 \%$ confidence interval (CI), 0.761-2.260; I-square, 46.86; $p=0.130$ ) not showing a significant increase of IGF-I/IGFBP3 ratio in HCC incidence (data not shown).

\section{Association of IGF1 level with TTP and OS}

Low IGF1 levels were predictive of a shorter TTP (OR, 2.74; 95\% CI, 1.92-3.90) and poorer OS (OR, 2.20; $95 \%$ CI, 1.81-2.68) in HCC patients, irrespective of the grade of hepatic dysfunction. No significant heterogeneity was observed among the studies. This suggests serum IGF1 level to be an independent prognostic factor for the survival (Figure 2A) and progression (Figure 2B) of HCC patients. The subgroup analysis indicated that use of different detection methods (ELISA and radioimmunoassay), research designs (clinical and cohort studies), and locations (Asia, North, America and Europe) had no significant influence on the TTP and OS of HCC patients (Table 4A and 4B).

\section{Serum IGF1 levels according to clinical characteristics}

The associations between clinical factors and baseline IGF1 levels are shown in Table 5. HCC patients with the hepatitis $\mathrm{C}$ virus $(\mathrm{HCV})$ infection 
Table 1: Characteristics of studies included in the review

(A) Studies of serum IGF-1 and IGFBP-3 levels and IGF-I/IGFBP-3 molar ratio among healthy, cirrhosis and HCC groups

\begin{tabular}{|c|c|c|c|c|c|c|c|c|c|c|}
\hline Study, year & Location, setting & Study design & $\begin{array}{l}\text { Study } \\
\text { period }\end{array}$ & Age, $y$ & $\begin{array}{c}\text { IGF-1/IGFBP-3 } \\
\text { assay }\end{array}$ & HCC diagnosis & $\mathrm{HCC}, n$ & $\begin{array}{l}\text { Cirrhosis } \\
\text { case, } n\end{array}$ & $\begin{array}{l}\text { Healthy } \\
\text { controls, } n\end{array}$ & $\begin{array}{c}\text { Adjusted } \\
\text { confounders }\end{array}$ \\
\hline Stuver et al, $2000^{2}$ & $\begin{array}{l}\text { USA, } \\
\text { Hospital-based }\end{array}$ & Case control & $1995-1998$ & $39-88$ & $\begin{array}{l}\text { Chemiluminescence } \\
\text { assay }\end{array}$ & Biopsy, AFP,US & 73 & NV & 111 & Gender, age \\
\hline $\begin{array}{l}\text { Mazziottiet et al, } \\
2002^{14}\end{array}$ & $\begin{array}{l}\text { Italy, Hospital- } \\
\text { based }\end{array}$ & Cohort study & $1995-2000$ & $43-81$ & $\begin{array}{l}\text { immunoradiometric } \\
\text { assay }\end{array}$ & US, biopsy & 20 & 84 & NV & Gender, age \\
\hline Mattera et al, $2003^{12}$ & $\begin{array}{l}\text { Italy, Hospital- } \\
\text { based }\end{array}$ & Cohort study & NA & $25-75$ & $\begin{array}{l}\text { immunoradiometric } \\
\text { assay }\end{array}$ & US, Biopsy & 63 & 40 & 150 & Age, diet \\
\hline Cujic et al, $2010^{39}$ & $\begin{array}{l}\text { Serbia, Hospital- } \\
\text { based }\end{array}$ & Cohort study & 2008 & $20-75$ & radioimmunoassay & US,CT & 8 & 24 & 31 & NA \\
\hline Major et al, $2010^{25}$ & $\begin{array}{l}\text { USA, population- } \\
\text { based }\end{array}$ & Cohort study & $1985-1988$ & $50-69$ & ELISA & $\begin{array}{l}\text { AFP, US,CT, } \\
\text { MRI, biopsy }\end{array}$ & 50 & NA & 400 & Age, \\
\hline Su et al, $2010^{22}$ & $\begin{array}{l}\text { Taiwan, Hospital- } \\
\text { based }\end{array}$ & $\begin{array}{l}\text { Cohort } \\
\text { study }\end{array}$ & 2005-2006 & $20-83$ & radioimmunoassay & Biopsy, AFP,US & 65 & NA & 165 & $\begin{array}{l}\text { Recruitment } \\
\text { center, date of } \\
\text { blood collection }\end{array}$ \\
\hline Rehem et a,1 $2011^{40}$ & $\begin{array}{l}\text { Egypt, Hospital- } \\
\text { based }\end{array}$ & Cohort study & 2011 & $24-69$ & $\begin{array}{l}\text { Immunoradiometric } \\
\text { assay }\end{array}$ & $\mathrm{CT}$ or/and AFP & 20 & 60 & 20 & NA \\
\hline Aleem et al, $2012^{41}$ & $\begin{array}{l}\text { Egypt, Hospital- } \\
\text { based }\end{array}$ & Cohort study & 2010-2011 & NA & ELISA & US, AFP & 62 & 79 & 100 & $\begin{array}{l}\text { Age, height, } \\
\text { BMI }\end{array}$ \\
\hline Adamek et al, $2013^{42}$ & $\begin{array}{l}\text { Poland, Hospital- } \\
\text { based }\end{array}$ & $\begin{array}{l}\text { Cohort } \\
\text { study }\end{array}$ & 2010-2012 & $18-63$ & $\begin{array}{l}\text { immunoenzymetric } \\
\text { assay, ELISA }\end{array}$ & USAFP & 61 & 37 & 15 & Age, gender \\
\hline Lukanovaet al,2014 & $\begin{array}{l}\text { European } \\
\text { countries, } \\
\text { population-based }\end{array}$ & $\begin{array}{l}\text { nested case- } \\
\text { control study }\end{array}$ & 2002-2006 & $35-75$ & ELISA & $\begin{array}{l}\text { AFP, US,CT, } \\
\text { MRI, biopsy }\end{array}$ & 125 & NA & 247 & $\begin{array}{l}\text { Recruitment } \\
\text { center, gender, } \\
\text { age, date of } \\
\text { blood collection }\end{array}$ \\
\hline Adachi et al, $2016^{4}$ & $\begin{array}{l}\text { Japan, } \\
\text { population-based }\end{array}$ & $\begin{array}{l}\text { nested case- } \\
\text { control study }\end{array}$ & $1997-2000$ & $40-79$ & $\begin{array}{l}\text { immunoradiometric } \\
\text { assay }\end{array}$ & $\begin{array}{l}\text { AFP, US,CT, } \\
\text { MRI, biopsy }\end{array}$ & 91 & NA & 263 & $\begin{array}{l}\text { gender, age, and } \\
\text { residential area } \\
\text {,Hepatitis viral } \\
\text { infection, body } \\
\text { mass index, } \\
\text { smoking, and } \\
\text { alcohol intake }\end{array}$ \\
\hline
\end{tabular}

\section{(B) Ability of serum IGF1 level to predict the progression and survival of HCC patients}

\begin{tabular}{|c|c|c|c|c|c|c|c|c|}
\hline $\begin{array}{l}\text { Study, } \\
\text { year }\end{array}$ & $\begin{array}{l}\text { Location, } \\
\text { setting }\end{array}$ & Study design & $\begin{array}{l}\text { Follow-up } \\
\text { Period, m }\end{array}$ & $\begin{array}{l}\text { age(mean or } \\
\text { median),y }\end{array}$ & $\begin{array}{c}\text { IGF-1/IGFBP-3 } \\
\text { assay }\end{array}$ & HCC diagnosis & Cases, $n$ & $\begin{array}{l}\text { Outcomes } \\
\text { index }\end{array}$ \\
\hline Treiber et al $2006^{26}$ & Germany, Hospital-based & Cohort study & 6 & 65.7 & ESILA & US,CT, MRI & 71 & OS, TTP \\
\hline Kaseb et al, 2011 27 & USA, Hospital-based & Cohort study & 96 & 60 & ELISA & biopsy, US & 288 & OS \\
\hline Shao et al, $2012^{28}$ & Taiwan, Hospital-based & Cohort study & 40 & 54 & ELISA & biopsy, AFP & 83 & OS, PFS \\
\hline Cho et al, $2013^{13}$ & Korea, Hospital-based & Cohort study & 72 & 57.1 & $\begin{array}{c}\text { immunoradiometric } \\
\text { assay }\end{array}$ & $\begin{array}{l}\text { AFP, US,CT, MRI, } \\
\text { biopsy }\end{array}$ & 91 & OS, TTR \\
\hline Cho et al, $2014^{29}$ & Korea, Hospital-based & Cohort study & 41.8 & 56 & $\begin{array}{c}\text { immunoradiometric } \\
\text { assay }\end{array}$ & $\begin{array}{l}\text { AFP,US,CT,MRI, } \\
\text { biopsy }\end{array}$ & 155 & OS, TTP \\
\hline Kaseb et al, $2014^{6}$ & USA, Hospital-based & Cohort study & 16.5 & 60 & ELISA & $\begin{array}{l}\text { AFP,US,CT, MRI, } \\
\text { biopsy }\end{array}$ & 155 & OS \\
\hline Abdel-Wahab et al, $2015^{15}$ & Egypt, Hospital-based & Cohort study & 6.5 & 63.2 & ELISA & Biopsy, CT & 100 & OS \\
\hline Elmashad et al, $2015^{16}$ & Egypt, Hospital-based & Cohort study & 8 & 51 & ELISA & $\mathrm{CT}$ or /and AFP & 89 & OS, TTP \\
\hline Liu, $2016^{36}$ & China, Hospital-based & Cohort study & 47 & 55 & ELISA & $\begin{array}{c}\text { AFP,US,CT, MRI, } \\
\text { biopsy }\end{array}$ & 128 & OS, TTP \\
\hline
\end{tabular}

had significantly lower IGF1 levels than those with the hepatitis B virus (HBV) infection $(p=0.034)$. HCC patients of Child-Pugh class $\mathrm{C}(p=0.002)$, Barcelona Clinic Liver Cancer Stage-B (BCLC-B) $(p<0.01)$, or BCLC-C $(p=0.019)$ had significantly lower baseline IGF1 levels. However, baseline IGF1 levels did not differ significantly according to age, gender, serum
AFP level, tumour nodularity, or vascular invasion $(p>0.05)$.

\section{Publication bias}

No evidence of publication bias was detected in nine studies of the ability of serum IGF1 level to predict the 
OS rate of HCC patients (Begg test, $p=0.083$; Egger test, $p=0.103$ ) (Figure 3).

\section{DISCUSSION}

High levels of circulating IGF-I and low levels of IGFBP-3 are reportedly associated with an increased risk of several common cancers, including those of the prostate, breast, colon, and lung [18-20]. However, no systematic review has evaluated the associations of IGF1 and IGFBP3 levels with HCC. We conducted a systematic review and meta-analysis of the association of serum IGFI and IGFBP3 levels with the risk of HCC. Low levels of IGF1 and IGFBP-3 were positively associated with the risk of HCC independently of the degree of impairment of liver function, consistent with previous reports [2, 21, 22]. Additionally, patients with cirrhosis had lower circulating IGF1 and IGFBP3 levels than healthy controls $(p<0.001)$. This is likely because of reduced secretion of the liver-derived factors IGF1 and IGFBP3 in cirrhosis and HCC patients with chronic liver damage and functional insufficiency [23].

The free form of IGF1 induces cell proliferation and inhibits apoptosis in bone, cartilage, the central nervous system, and the kidneys. The IGF1 to IGFBP3 molar ratio represents the level of active IGF1 [24], and patients with an IGF1 concentration higher than their IGFBP3 level are at an increased risk of liver cancer [25]. However, no significant association between the IGFI/IGFBP3 molar ratio and the risk of $\mathrm{HCC}(\mathrm{OR}, 1.311 ; 95 \% \mathrm{CI}$, 0.761-2.260) was detected.

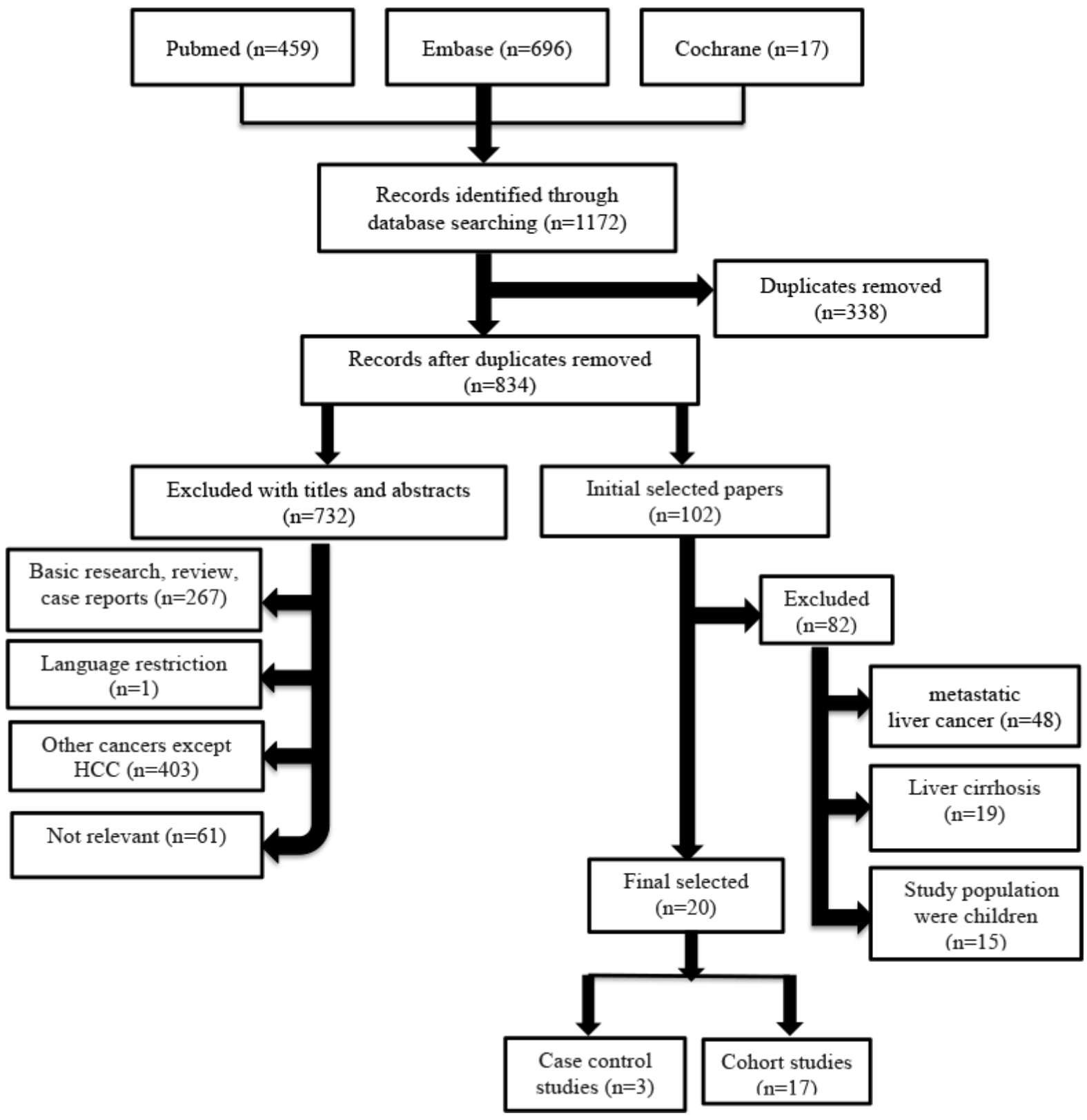

Figure 1: Flow chart of the studies selected for systematic review and meta-analysis. 


\begin{tabular}{lccc}
\hline & $\boldsymbol{n}$ & Mean \pm SD & $\boldsymbol{p}$ value \\
\hline Serum IFG-1 level (ng/ml) & & & $<0.001$ \\
Healthy population & 1255 & $181.34 \pm 107.89$ & 0.037 \\
Cirrhosis patients & 324 & $117.77 \pm 109.69$ & $102.91 \pm 85.89$ \\
HCC patients & 432 & & $<0.001$ \\
Serum IFGBP3 level (ng/ml) & & $2608.35 \pm 787.27$ & 0.026 \\
Healthy population & 665 & $1278.84 \pm 777.30$ & $1092.38 \pm 736.06$ \\
Cirrhosis patients & 156 & 175 & \\
HCC patients & & & \\
\hline
\end{tabular}

In HCC patients, a low serum IGF1 level was predictive of a shorter TTP (OR, 2.74; 95\% CI, 1.92$3.90)$ and poorer OS (OR, 2.20; 95\% CI, 1.81-2.68), with no heterogeneity (I-square $=0)$, irrespective of the grade of hepatic dysfunction, which is consistent with previous reports $[6,13,15,26-29]$. Nine of the studies used identical statistical methods: (1) receiver-operating characteristic (ROC) curves for censored survival data to identify the optimum cut-off value for predicting outcome; [30] and (2) Cox proportional hazard regression analysis to evaluate independent risk factors for disease progression and OS [31] after adjustment for age, gender, $\mathrm{HBV} / \mathrm{HCV}$ infection, AFP level, Child-Pugh class, BCLC stage, tumour nodularity, and vascular invasion. Serum IGF1 level was the most significant predictor of HCC progression and survival. A prospective study reported that a low IGF-I concentration at least 5 years before cancer diagnosis was associated with an increased risk of liver cancer [25]. Further, larger-scale studies of the ability of ILGF-1 level to predict HCC are warranted.

Additionally, circulating IGF-1 level was correlated with virus infection, Child-Pugh class, and BCLC stage of HCC patients. Therefore, the circulating IGF-1 level was associated with HCC progression. The circulating IGF-1 level is reportedly significantly correlated with survival, the synthetic function of the liver, and tumour parameters $[27,32]$. Moreover, integrating plasma insulin-like growth factor-1 level into the Child-Turcotte-Pugh score (IGFCTP score) resulted in improved risk stratification of HCC patients $[6,15]$. The IGF-CTP score should thus be validated in further studies.

We analysed all available prospective studies that adjusted for potential risk factors, such as liver function and the clinical characteristics of HCC patients. However, this study had several limitations. First, the meta-analysis was vulnerable to the bias in the original studies, and the IGF1 and IGFBP3 assays and study design were not standardised, which led to different IGF1 and IGFBP3 levels among the studies. Future prospective studies should use a uniform study design and identical assays. Second, previous studies showed that energy and protein intake were associated with IGF1 and IGFBP3 concentrations ${ }^{33,34}$, but we did not adjust for dietary parameters. Third, most of the included studies involved hospitalised patients, who may not be representative of the general population, likely leading to overestimation of the risk of HCC. Finally, the number of eligible studies was small, which may have influenced the accuracy of the results.

In conclusion, circulating IGF1 and IGFBP3 levels were positively associated with the incidence of HCC,
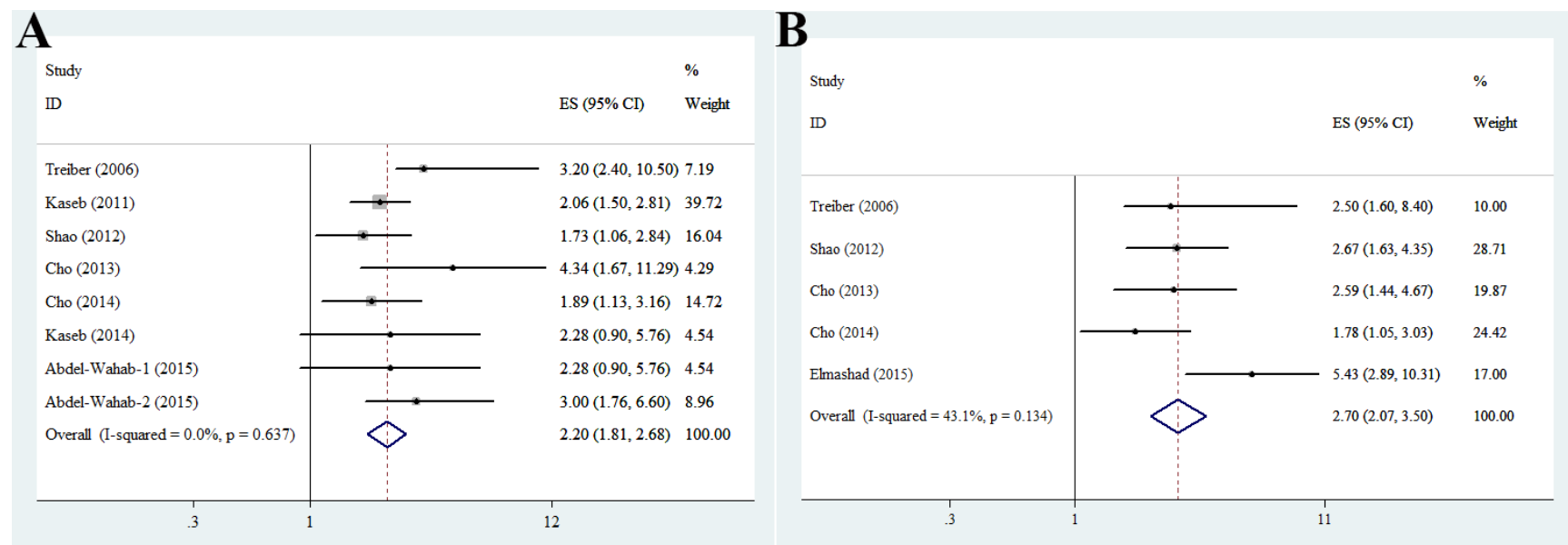

Figure 2: Association between serum IGF1 level and HCC. (A) Overall survival (OS); (B) time-to-progression (TTP). 
Table 3: Factors associated with serum IGF1 levels in the healthy, cirrhosis, and HCC groups

\begin{tabular}{|c|c|c|c|c|c|c|c|c|c|}
\hline \multirow[b]{2}{*}{ Factors and subset } & \multicolumn{3}{|c|}{ Health control } & \multicolumn{3}{|c|}{ Cirrhosis } & \multicolumn{3}{|c|}{$\mathrm{HCC}$} \\
\hline & $n$ & Mean \pm SD & $p$ value & $n$ & Mean \pm SD & $p$ value & $n$ & Mean \pm SD & $p$ value \\
\hline \multicolumn{10}{|l|}{ Detection methods } \\
\hline ELISA & 626 & $190.61 \pm 104.78$ & 0.002 & 116 & $190.69 \pm 139.42$ & $<0.001$ & 165 & $118.71 \pm 93.41$ & 0.005 \\
\hline Radioimmunoassay & 629 & $172.10 \pm 110.20$ & & 208 & $77.11 \pm 57.73$ & & 176 & $90.68 \pm 90.48$ & \\
\hline \multicolumn{10}{|l|}{ Research designs } \\
\hline Case-control study & 374 & $129.14 \pm 63.20$ & $<0.001$ & & & & 53 & $65.87 \pm 45.99$ & 0.008 \\
\hline cohort study & 415 & $145.69 \pm 50.26$ & $<0.001$ & 121 & $68.00 \pm 33.50$ & $<0.001$ & 70 & $91.94 \pm 57.63$ & 0.056 \\
\hline cross-section study & 466 & $254.98 \pm 131.05$ & & 203 & $147.44 \pm 127.29$ & & 218 & $117.52 \pm 106.54$ & \\
\hline \multicolumn{10}{|l|}{ Location settings } \\
\hline hospital-based & 592 & $236.75 \pm 124.85$ & $<0.001$ & 324 & $117.77 \pm 109.69$ & & 291 & $102.36 \pm 98.12$ & 0.367 \\
\hline population-based & 663 & $131.86 \pm 54.19$ & & & & & 50 & $115.2 \pm 51.61$ & \\
\hline \multicolumn{10}{|l|}{ Study locations } \\
\hline Asia & 548 & $209.26 \pm 143.03$ & $<0.001$ & 139 & $168.28 \pm 139.32$ & & 147 & $144.19 \pm 114.71$ & $<0.001$ \\
\hline North America & 511 & $152.47 \pm 54.12$ & $<0.001$ & & & & 103 & $89.82 \pm 54.51$ & $<0.001$ \\
\hline Europe & 196 & $178.53 \pm 73.61$ & & 185 & $79.82 \pm 56.46$ & $<0.001$ & 91 & $56.04 \pm 51.40$ & \\
\hline
\end{tabular}

and the IGF1 level emerged as an independent prognostic factor for the progression and survival of HCC patients. Therefore, further large-scale, well-designed studies that consider a larger number of confounding factors are warranted.

\section{MATERIALS AND METHODS}

\section{Search strategy}

Case-control and cohort studies were identified by searching PubMed, EMBASE, and the Cochrane Library using the following keywords: Insulin-like growth factor-I, insulin-like growth factor binding protein 3 , and hepatocellular carcinomas. Only English-language publications were included in the study. The databases were searched for articles published up to October 2016.

\section{Selection of studies and data extraction}

we included observational studies that met all of the following inclusion criteria: (1) case-control or cohort design; (2) use of adult subjects; (3) inclusion of a healthy control group and HCC patients with cirrhosis; (4) measurement of serum levels of IGF1 and/or IGFBP3 and calculation of means \pm SDs; (5) calculation of odds ratio (OR) or relative risk (RR) of IGF1 serum level for HCC progression and survival; and (6) written in the English language.

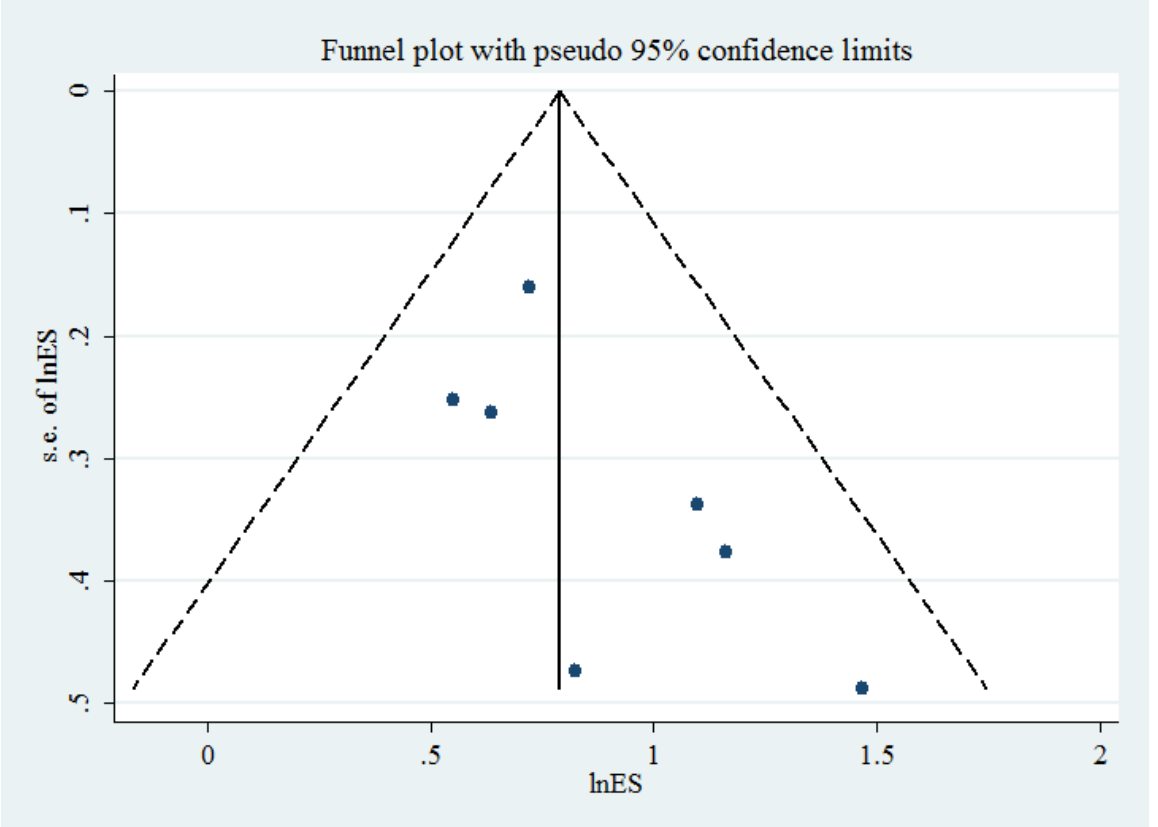

Figure 3: Publication bias in studies of the association between serum IGF1 level and overall survival of HCC patients. 
Table 4: Subgroup analysis of the association between serum IGF1 level and HCC (A) Overall survival (OS)

\begin{tabular}{|c|c|c|c|c|}
\hline Factors & Studies, $n$ & OS for HCC (95\%CI) & $r^{2}$ & Model used \\
\hline \multicolumn{5}{|l|}{ Detection method } \\
\hline ELISA & 6 & $2.311(1.858-2.874)$ & $31.4 \%$ & Fixed effects \\
\hline Radioimmunoassay & 2 & $2.279(1.448-3.587)$ & $55.6 \%$ & Fixed effects \\
\hline \multicolumn{5}{|l|}{ Study design } \\
\hline Clinical trail & 3 & $2.073(1.615-2.660)$ & $0 \%$ & Fixed effects \\
\hline Cohort & 5 & $2.745(1.993-3.781)$ & $31.8 \%$ & Fixed effects \\
\hline \multicolumn{5}{|l|}{ Study location } \\
\hline Asia & 5 & $2.489(1.922-3.223)$ & $41.6 \%$ & Fixed effects \\
\hline North America & 2 & $2.082(1.546-2.802)$ & $0 \%$ & Fixed effects \\
\hline Europe & 1 & $3.2(2.4-10.5)$ & & \\
\hline
\end{tabular}

\section{(B) Time-to-progression (TTP)}

\begin{tabular}{ccccc}
\hline Factors & Studies, $\boldsymbol{n}$ & TTP for HCC (95\%CI) & $\boldsymbol{I}^{\mathbf{2}}$ & Model used \\
\hline Detection method & & & & \\
ELISA & 3 & $3.275(2.305-4.653)$ & $43.1 \%$ & Fixed effects \\
Radioimmunoassay & 2 & $2.109(1.422-3.128)$ & $0 \%$ & Fixed effects \\
Study design & & & & \\
Clinical trail & 2 & $2.623(1.721-3.997)$ & $0 \%$ & Fixed effects \\
Cohort & 3 & $2.873(1.530-5.394)$ & $71.4 \%$ & Random effects \\
Study location & & & & \\
Asia & 4 & $2.718(2.062-3.583)$ & $57.1 \%$ & Fixed effects \\
Europe & 1 & $2.5(1.6-8.4)$ & & \\
\hline
\end{tabular}

\section{Data extraction and quality assessment}

Data extraction was conducted independently by J.W. and Y.-C.L., and discrepancies were resolved by D.M., H.-Y.J., L.-H.G., and W.-J.Z. before the final analysis. The following data were collected from each study: author, year of publication, study country, study setting, total number of subjects in each group, serological detection method for IGF1 and IGFBP3, basis for HCC diagnosis, and statistical adjustments made. The quality of the included studies was assessed using the NewcastleOttawa Scale (NOS) [35], which was developed to assess the quality of nonrandomised studies in meta-analyses. On this scale, observational studies are scored in three categories: selection (four questions) and comparability (two questions) of the study group, and ascertainment of the outcome of interest (three questions). All questions have a score of one, with the exception of those addressing the comparability of study groups, for which separate points are awarded for controlling for age and/ or sex (maximum, two points). Studies with more than five points were included in the meta-analysis; one study [36] did not meet this criterion and was excluded from the analysis of the survival of HCC patients (Supplementary Figure 1).

\section{Outcomes}

The primary analysis assessed the association of serum IGF1 and IGFBP3 levels with the incidence of HCC and the ability of a low IGF1 serum level to predict HCC progression and survival. The serum IGF1 levels of the HCC patients were analysed according to their clinical characteristics, such as age, gender, AFP level, ChildPugh class, BCLC stage, tumour nodularity, and vascular invasion.

\section{Statistical analysis}

statistical analysis was conducted using STATA 12.0 software (StataCorp LP, College Station, TX, USA). The Cochran $\mathrm{Q}$ chi-square test and the $\mathrm{I}^{2}$ statistic were used to assess heterogeneity among the studies [37]. An $\mathrm{I}^{2}$ value of $>50 \%$ or a $p$-value of $<0.05$ for the Q-statistic was taken to indicate significant heterogeneity [38]. We used a fixed-effects model to estimate pooled odds ratios (ORs) 
Table 5: Serum levels of IGF1 according to the clinical characteristics of HCC patients

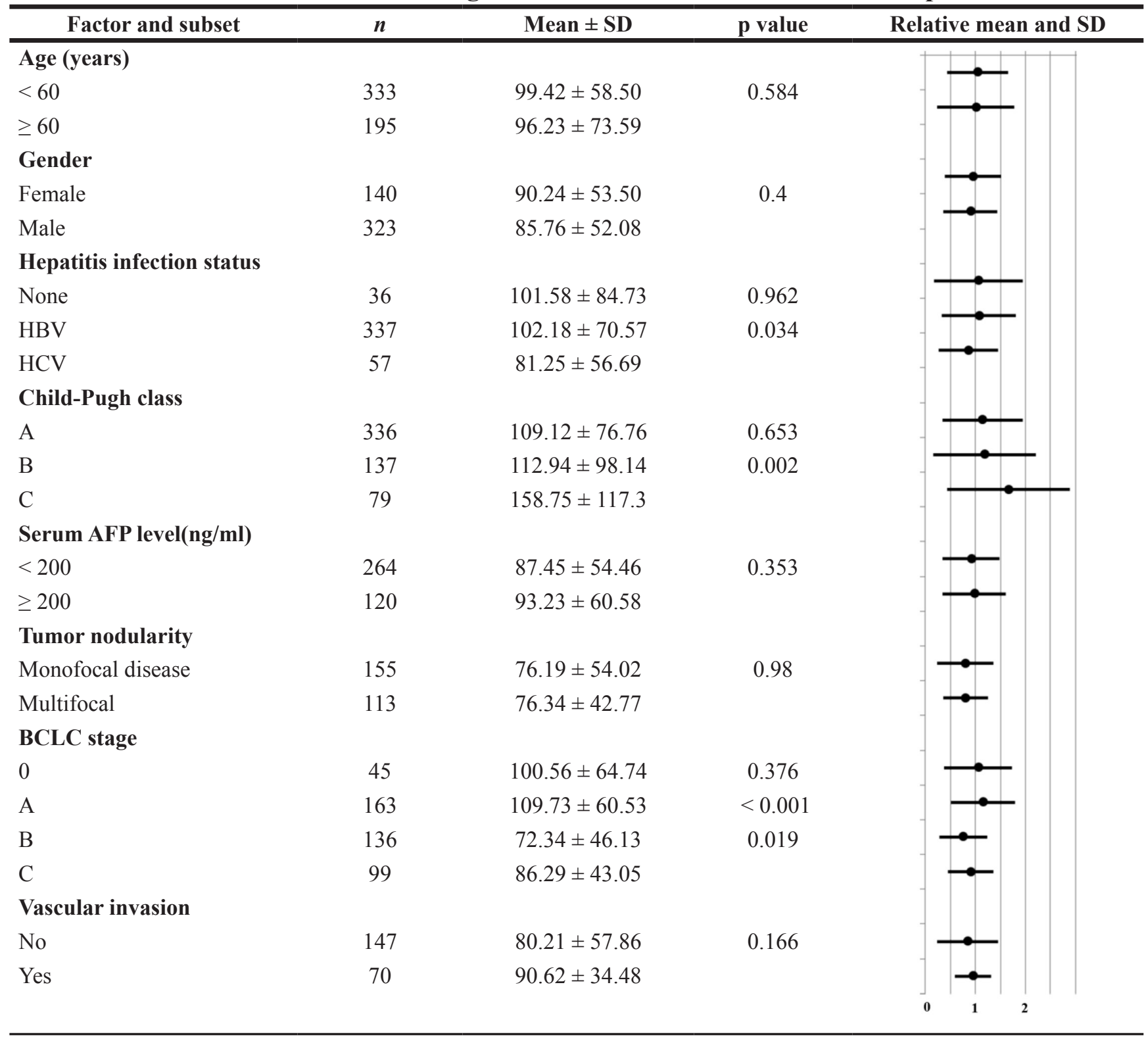

and corresponding 95\% confidence intervals (CIs) for HCC progression and survival. Additionally, the serum IGF1 and IGFBP levels of the healthy, cirrhosis, and HCC groups were subjected to one-way analysis of variance (ANOVA). Serum IGF1 levels were analysed according to the clinical characteristics of the HCC patients. Publication bias was analysed using a Begg funnel plot and the Egger test [43].

\section{Authors' contributions}

Y.C. Li and B. Ruan conceived the study and revised the important intellectual content of the manuscript. J. Wang and Y.C. Li made substantial contributions to the study design as well as to the acquisition, analysis, and interpretation of data. M. Deng, H. Y. Jiang, L. H. Guo, and W.J. Zhou participated in designing the study and acquiring, analysing, and interpreting the data. All authors read and approved the final manuscript.

\section{CONFLICTS OF INTEREST}

The authors declare that the research was conducted in the absence of any commercial or financial relationships that could be construed as potential conflicts of interest.

\section{GRANT SUPPORT}

This work was supported by Fundamental Research Funds for the Central Universities (2014XZZX008). 


\section{REFERENCES}

1. Maki RG. Small is beautiful: insulin-like growth factors and their role in growth, development, and cancer. J Clin Oncol. 2010; 28:4985-95. https://doi.org/10.1200/ JCO.2009.27.5040.

2. Stuver SO, Kuper H, Tzonou A, Lagiou P, Spanos E, Hsieh CC, Mantzoros C, Trichopoulos D. Insulin-like growth factor-1 in hepatocellular carcinoma and metastatic liver cancer in men. Int J Cancer. 2000; 87:118-21. https:// doi.org/10.1002/1097-0215(20000701)87:1<118::AIDIJC17>3.0.CO;2-W.

3. Lukanova A, Becker S, Hüsing A, Schock H, Fedirko V, Trepo E, Trichopoulou A, Bamia C, Lagiou P, Benetou V, Trichopoulos D, Nöthlings U, Tjønneland A, et al. Prediagnostic plasma testosterone, sex hormone-binding globulin, IGF-I and hepatocellular carcinoma: etiological factors or risk markers? Int J Cancer. 2014; 134:164-73. https://doi.org/10.1002/ijc.28342.

4. Adachi Y, Nojima M, Mori M, Matsunaga Y, Akutsu N, Sasaki S, Endo T, Kurozawa Y, Wakai K, Tamakoshi A, and for JACC Study. Insulin-like growth factor-related components and the risk of liver cancer in a nested casecontrol study. Tumour Biol. 2016; 37:15125-32. https://doi. org/10.1007/s13277-016-5360-z.

5. Abdel-Wahab R, Shehata S, Hassan MM, Habra MA, Eskandari G, Tinkey PT, Mitchell J, Lee JS, Amin HM, Kaseb AO. Type I insulin-like growth factor as a liver reserve assessment tool in hepatocellular carcinoma. J Hepatocell Carcinoma. 2015; 2:131-42. https://doi. org/10.2147/JHC.S81309.

6. Kaseb AO, Xiao L, Hassan MM, Chae YK, Lee JS, Vauthey JN, Krishnan S, Cheung S, Hassabo HM, Aloia T, Conrad C, Curley SA, Vierling JM, et al. Development and validation of insulin-like growth factor-1 score to assess hepatic reserve in hepatocellular carcinoma. J Natl Cancer Inst. 2014; 106:dju088. https://doi.org/10.1093/jnci/dju088.

7. Renehan AG, Brennan BM. Acromegaly, growth hormone and cancer risk. Best Pract Res Clin Endocrinol Metab. 2008; 22:639-57. https://doi.org/10.1016/j. beem.2008.08.011.

8. Pollak MN, Schernhammer ES, Hankinson SE. Insulinlike growth factors and neoplasia. Nat Rev Cancer. 2004; 4:505-18. https://doi.org/10.1038/nrc1387.

9. Yu H, Rohan T. Role of the insulin-like growth factor family in cancer development and progression. J Natl Cancer Inst. 2000; 92:1472-89. https://doi.org/10.1093/jnci/92.18.1472.

10. Aishima S, Basaki Y, Oda Y, Kuroda Y, Nishihara Y, Taguchi K, Taketomi A, Maehara Y, Hosoi F, Maruyama Y, Fotovati A, Oie S, Ono M, et al. High expression of insulin-like growth factor binding protein-3 is correlated with lower portal invasion and better prognosis in human hepatocellular carcinoma. Cancer Sci. 2006; 97:1182-90. https://doi.org/10.1111/j.1349-7006.2006.00322.x.
11. Samani AA, Yakar S, LeRoith D, Brodt P. The role of the IGF system in cancer growth and metastasis: overview and recent insights. Endocr Rev. 2007; 28:20-47. https://doi. org/10.1210/er.2006-0001.

12. Mattera D, Capuano G, Colao A, Pivonello R, Manguso F, Puzziello A, D'Agostino L. Increased IGF-I : IGFBP-3 ratio in patients with hepatocellular carcinoma. Clin Endocrinol (Oxf). 2003; 59:699-706. https://doi.org/10.1046/j.13652265.2003.01909.x.

13. Cho EJ, Lee JH, Yoo JJ, Choi WM, Lee MJ, Cho Y, Lee DH, Lee YB, Kwon JH, Yu SJ, Lee JM, Suh KS, Kim K, et al. Serum insulin-like growth factor-I level is an independent predictor of recurrence and survival in early hepatocellular carcinoma: a prospective cohort study. Clin Cancer Res. 2013; 19:4218-27. https://doi.org/10.1158/1078-0432.CCR12-3443.

14. Mazziotti G, Sorvillo F, Morisco F, Carbone A, Rotondi M, Stornaiuolo G, Precone DF, Cioffi M, Gaeta GB, Caporaso N, Carella C. Serum insulin-like growth factor-I evaluation as a useful tool for predicting the risk of developing hepatocellular carcinoma in patients with hepatitis $\mathrm{C}$ virus-related cirrhosis: a prospective study. Cancer. 2002; 95:2539-45. https://doi.org/10.1002/cncr.11002.

15. Abdel-Wahab R, Shehata S, Hassan MM, Xiao L, Lee JS, Cheung S, Essa HH, Hassabo HM, Shalaby AS, Mosad E, Raghav K, Rashid A, Wolff RA, et al. Validation of an IGF-CTP scoring system for assessing hepatic reserve in Egyptian patients with hepatocellular carcinoma. Oncotarget. 2015; 6:21193-207. https://doi.org/10.18632/ oncotarget. 4176.

16. Elmashad N, Ibrahim WS, Mayah WW, Farouk M, Ali LA, Taha A, Elmashad W. Predictive value of serum insulin-like growth factor-1 in hepatocellular carcinoma. Asian Pac J Cancer Prev. 2015; 16:613-19. https://doi.org/10.7314/ APJCP.2015.16.2.613.

17. Bruix J, Sherman M, and Practice Guidelines Committee, American Association for the Study of Liver Diseases. Management of hepatocellular carcinoma. Hepatology. 2005; 42:1208-36. https://doi.org/10.1002/hep.20933.

18. Chen W, Wang S, Tian T, Bai J, Hu Z, Xu Y, Dong J, Chen F, Wang X, Shen H. Phenotypes and genotypes of insulinlike growth factor-1, IGF-binding protein-3 and cancer risk: evidence from 96 studies. Eur J Hum Genet. 2009; 17:1668-75. https://doi.org/10.1038/ejhg.2009.86.

19. Key TJ, Appleby PN, Reeves GK, Roddam AW, and Endogenous Hormones and Breast Cancer Collaborative Group. Insulin-like growth factor-1 (IGF1), IGF binding protein 3 (IGFBP3), and breast cancer risk: pooled individual data analysis of 17 prospective studies. Lancet Oncol. 2010; 11:530-42. https://doi.org/10.1016/S14702045(10)70095-4.

20. Gu F, Schumacher FR, Canzian F, Allen NE, Albanes D, Berg CD, Berndt SI, Boeing H, Bueno-de-Mesquita HB, Buring JE, Chabbert-Buffet N, Chanock SJ, Clavel- 
Chapelon F, et al. Eighteen insulin-like growth factor pathway genes, circulating levels of IGF-I and its binding protein, and risk of prostate and breast cancer. Cancer Epidemiol Biomarkers Prev. 2010; 19:2877-87. https://doi. org/10.1158/1055-9965.EPI-10-0507.

21. Völzke H, Nauck M, Rettig R, Dörr M, Higham C, Brabant $\mathrm{G}$, Wallaschofski H. Association between hepatic steatosis and serum IGF1 and IGFBP-3 levels in a population-based sample. Eur J Endocrinol. 2009; 161:705-13. https://doi. org/10.1530/EJE-09-0374.

22. Su WW, Lee KT, Yeh YT, Soon MS, Wang CL, Yu ML, Wang SN. Association of circulating insulin-like growth factor-1 with hepatocellular carcinoma: one cross-sectional correlation study. J Clin Lab Anal. 2010; 24:195-200. https://doi.org/10.1002/jcla.20320.

23. Fernández-Rodriguez CM, Prada I, Andrade A, Moreiras M, Guitián R, Aller R, Lledó JL, Cacho G, Quiroga J, Prieto J. Disturbed synthesis of insulinlike growth factor I and its binding proteins may influence renal function changes in liver cirrhosis. Dig Dis Sci. 2001; 46:1313-20. https://doi. org/10.1023/A:1010631800505.

24. Ma J, Pollak MN, Giovannucci E, Chan JM, Tao Y, Hennekens CH, Stampfer MJ. Prospective study of colorectal cancer risk in men and plasma levels of insulinlike growth factor (IGF)-I and IGF-binding protein-3. J Natl Cancer Inst. 1999; 91:620-25. https://doi.org/10.1093/ jnci/91.7.620.

25. Major JM, Stolzenberg-Solomon RZ, Pollak MN, Snyder K, Virtamo J, Albanes D. Insulin-like growth factors and liver cancer risk in male smokers. Br J Cancer. 2010; 103:108992. https://doi.org/10.1038/sj.bjc.6605842.

26. Treiber G, Wex T, Röcken C, Fostitsch P, Malfertheiner P. Impact of biomarkers on disease survival and progression in patients treated with octreotide for advanced hepatocellular carcinoma. J Cancer Res Clin Oncol. 2006; 132:699-708. https://doi.org/10.1007/s00432-006-0118-4.

27. Kaseb AO, Morris JS, Hassan MM, Siddiqui AM, Lin E, Xiao L, Abdalla EK, Vauthey JN, Aloia TA, Krishnan S, Abbruzzese JL. Clinical and prognostic implications of plasma insulin-like growth factor-1 and vascular endothelial growth factor in patients with hepatocellular carcinoma. J Clin Oncol. 2011; 29:3892-99. https://doi.org/10.1200/ JCO.2011.36.0636.

28. Shao YY, Huang CC, Lin SD, Hsu CH, Cheng AL. Serum insulin-like growth factor-1 levels predict outcomes of patients with advanced hepatocellular carcinoma receiving antiangiogenic therapy. Clin Cancer Res. 2012; 18:399297. https://doi.org/10.1158/1078-0432.CCR-11-2853.

29. Cho E, Kim HC, Lee JH, You JJ, Choi WM, Cho YY, Lee MJ, Cho Y, Lee DH, Lee YB, Yu SJ, Kim YJ, Yoon JH, et al. Serum insulin-like growth factor-1 predicts disease progression and survival in patients with hepatocellular carcinoma who undergo transarterial chemoembolization. PLoS One. 2014; 9:e90862. https://doi.org/10.1371/journal. pone.0090862.
30. Heagerty PJ, Lumley T, Pepe MS. Time-dependent ROC curves for censored survival data and a diagnostic marker. Biometrics. 2000; 56:337-44. https://doi.org/10.1111/ j.0006-341X.2000.00337.x.

31. Grambsch PM, Therneau TM. Proportional hazards tests and diagnostics based on weighted residuals. Biometrika. 1994; 81:515-26. https://doi.org/10.1093/biomet/81.3.515.

32. Kaseb AO, Abbruzzese JL, Vauthey JN, Aloia TA, Abdalla EK, Hassan MM, Lin E, Xiao L, El-Deeb AS, Rashid A, Morris JS. I-CLIP: improved stratification of advanced hepatocellular carcinoma patients by integrating plasma IGF-1 into CLIP score. Oncology. 2011; 80:373-81. https:// doi.org/10.1159/000329040.

33. Crowe FL, Key TJ, Allen NE, Appleby PN, Roddam A, Overvad K, Grønbaek H, Tjønneland A, Halkjaer J, Dossus L, Boeing H, Kröger J, Trichopoulou A, et al. The association between diet and serum concentrations of IGF-I, IGFBP-1, IGFBP-2, and IGFBP-3 in the European Prospective Investigation into Cancer and Nutrition. Cancer Epidemiol Biomarkers Prev. 2009; 18:1333-40. https://doi. org/10.1158/1055-9965.EPI-08-0781.

34. Norat T, Dossus L, Rinaldi S, Overvad K, Grønbaek H, Tjønneland A, Olsen A, Clavel-Chapelon F, Boutron-Ruault MC, Boeing H, Lahmann PH, Linseisen J, Nagel G, et al. Diet, serum insulin-like growth factor-I and IGF-binding protein-3 in European women. Eur J Clin Nutr. 2007; 61:91-98. https://doi.org/10.1038/sj.ejcn.1602494.

35. Wells GA, Shea B, O'Connell D, Peterson J, Welch V, Losos M, Tugwell P. The Newcastle-Ottawa Scale (NOS) for assessing the quality of nonrandomised studies in metaanalyses. Available from: http:/www.ohri.ca/programs/ clinical_epidemiology/oxford.asp.

36. Liu S, Liu Y, Jiang X. Prognostic significance of serum insulin-like growth factor-1 in patients with hepatocellular carcinoma following transarterial chemoembolization. Exp Ther Med. 2016; 11:607-12. https://doi.org/10.3892/ etm.2015.2949.

37. Demets DL. Methods for combining randomized clinical trials: strengths and limitations. Stat Med. 1987; 6:341-50. https://doi.org/10.1002/sim.4780060325.

38. DerSimonian R, Laird N. Meta-analysis in clinical trials. Control Clin Trials. 1986; 7:177-88. https://doi. org/10.1016/0197-2456(86)90046-2.

39. Cujic D, Golubovic S, Bojic-Trbojevic Z, Ilic N, Baricevic I, Nedic O. Differential diagnosis of liver diseases using serum biomarkers. J BUON. 2010; 15:141-46.

40. Rehem RN, El-Shikh WM. Serum IGF-1, IGF2 and IGFBP-3 as parameters in the assessment of liver dysfunction in patients with hepatic cirrhosis and in the diagnosis of hepatocellular carcinoma. Hepatogastroenterology. 2011; 58:949-54.

41. Aleem E, Elshayeb A, Elhabachi N, Mansour AR, Gowily A, Hela A. Serum IGFBP-3 is a more effective predictor than IGF-1 and IGF-2 for the development of hepatocellular 
carcinoma in patients with chronic HCV infection. Oncol Lett. 2012; 3:704-12. https://doi.org/10.3892/ol.2011.546.

42. Adamek A, Kasprzak A, Mikoś H, Przybyszewska W, Seraszek-Jaros A, Czajka A, Sterzyńska K, Mozer-Lisewska I. The insulin-like growth factor-1 and expression of its binding protein-3 in chronic hepatitis $\mathrm{C}$ and hepatocellular carcinoma. Oncol Rep. 2013; 30:1337-45. https://doi. org/10.3892/or.2013.2546.
43. Egger M, Davey Smith G, Schneider M, Minder C. Bias in meta-analysis detected by a simple, graphical test. BMJ. 1997; 315:629-34. https://doi.org/10.1136/ bmj.315.7109.629. 